\title{
Kualitas Pelayanan Publik Terhadap Indeks Kepuasan Masyarakat Di Puskesmas Rappang
}

\author{
1)/ka Fitria, ${ }^{2)}$ Muhammad Arisal Asad, ${ }^{3)}$ Lukman \\ Fakultas IImu Sosial dan IImu Politik, Universitas Muhammadiyah Sidenreng Rappang \\ ikafitria43162001.1b@gmail.com
}

\begin{abstract}
Abstrak
Kualitas pelayanan publik di Puskesmas Rappang dan untuk mengetahui indeks kepuasan masyarakat di Puskesmas Rappang, dan untuk mengetahui pengaruh kualitas pelayanan publik terhadap indeks kepuasan masyarakat di Puskesmas Rappang. Metode pendekatan yang digunakan dalam penelitian ini yaitu pendekatan dekriptif kuantitatif. Populasi dalam penelitian ini adalah 4983 orang masyarakat yang telah terhitung sebagai pasien yang terdaftar di puskesmas sejak tahun 2019-2020. Teknik sampel yang digunakan adalah Random Sampling dengan menggunakan rumus slovin sehingga diperoleh sampel sebesar 98 orang. Teknik pengumpulan data yang dilakukan dengan menggunakan kuisioner, observasi dan studi pustaka. Data yang terkumpul selanjutnya diolah menggunakan teknik analisis deskriptif kuantitif dengan bantuan SPSS 21.0 dengan skala pengukuran menggunakan Skala Likert. Hasil penelitian menunjukkan bahwa kualitas pelayanan di Puskesmas Rappang berada pada kategori kurang baik dengan ratarata persentase sebesar 56,8\%, indeks kepuasan masyarakat di Puskesmas Rappang berada dalam ketegori kurang baik dengan rata-rata persentase sebesar $60 \%$, dan pengaruh kualitas pelayanan terhadap indeks kepuasan masyarakat dengan persentase sebesar $55,7 \%$ berbengaruh.
\end{abstract}

Kata Kunci: Kualitas Pelayanan Publik, Kepuasan Masyarakat

\begin{abstract}
Determine the quality of public services at the Rappang Puskesmas, to determine the community satisfaction index at the Rappang Puskesmas, and to determine the effect of the quality of public services on the community satisfaction index at the Rappang Puskesmas. The method used in this research is quantitative descriptive approach. The population in this study was 4983 people who have been counted as patients registered at the health center since 2019-2020. The sampling technique used was Random Sampling using the Slovin formula so that a sample of 98 people was obtained. Data collection techniques are carried out using questionnaires, observation and literature study. The collected data is then processed using a quantitative descriptive analysis technique with the help of SPSS 21.0 with a measurement scale using a Likert Scale. The results showed that the quality of service at the Rappang Puskesmas was in the poor category with an average percentage of $56.8 \%$, the community satisfaction index at the Puskesmas Rappang was in the poor category with an average percentage of $60 \%$, and the effect of the quality of service on community satisfaction index with a percentage of $55.7 \%$ influential.
\end{abstract}

Keywords: Public Service Quality, Community Satisfaction Index 


\section{A. PENDAHULUAN}

Kualitas pelayanan merupakan ukuran seberapa baik tingkat layanan yang diberikan mampu sesuai dengan harapan penerima layanan. Pemerintah selaku penyelenggara pelayanan mempunyai kewajiban untuk memberikan pelayanan sebaik-baiknya kepada seluruh masyarakat Indonesia tanpa terkecuali. Pelayanan yang diberikan diharapkan mampu sesuai dengan harapan masyarakat sebagai penerima layanan. Menurut Fitzsimmons (dalam Sellang, 2016) mengatakan bahwa "customer satisfaction with service quality can be defined perception of received with expectation of service desired" (maksudnya rasa puas seseorang terhadap suatu layanan bisa dilihat dengan membandingkan pandangan mengenai pelayanan yang diterima dengan pelayanan yang diharapkan).

Kepuasan masyarakat dapat dicapai jika aparatur pemerintah selaku penyelenggara layanan, baik secara langsung ataupun tidak langsung berusaha serta berkeinginan untuk memberikan pelayanan yang berkualitas. Kepuasan masyarakat bergantung pada baik tidaknya pelayanan yang diterima. Kepuasan masyarakat terhadap kualitas pelayanan yang diterimanya dapat diukur dengan Indeks Kepuasan Masyarakat atau IKM. Indeks kepuasan masyarakat merupakan informasi mengenai tingkat kepuasan masyarakat terkait pelayanan yang diberikan oleh aparatur penyelenggara pelayanan publik yang diperoleh dari hasil pengukuran secara kualitatif dan kuantitatif atas pendapat masyarakat. Salah satu kebutuhan dasar masyarakat adalah kesehatan. Pusat kesehatan masyarakat atau Puskesmas merupakan penyelenggara pelayanan kesehatan yang bertanggungjawab memberikan pelayanan kesehatan kepada seluruh masyarakat yang berdomisili di wilayah kerjanya. Keberadaan puskesmas sendiri diharapkan dapat membantu memenuhi kebutuhan masyarakat dalam mendapatkan pelayanan kesehatan.

Berkaitan dengan penjelasan yang telah dijabarkan diatas, hal yang menjadi masalah untuk diperhatikan dalam peningkatan kepuasan pasien (masyarakat) adalah kualitas pelayanan yang diberikan oleh penyedia layanan kesehatan. Masyarakat yang datang berobat masih merasa tidak puas dengan pelayanan yang mereka terima di Puskesmas Rappang yang di sebabkan karna kualitas pelayanan yang diberikan oleh Puskesmas masih belum memenuhi dimensi kualitas pelayanan yang baik seperti Tangbiles, responsiviness, Reliability, Assurance dan Empathy. Sehingga penulis tertarik merumuskan judul "Kualitas Pelayanan Publik terhadap Indeks Kepuasan Masyarakat Rappang" dengan tujuan yang ingin dicapai dalam untuk mengetahui bagaimana kualitas pelayanan di Puskesmas Rappang, untuk mengetahui bagaimana Indeks Kepuasan Masyarakat di Puskesmas Rappang, dan untuk mengetahui bagaimana pengaruh kualitas pelayanan publik terhadap Indeks Kepuasan Masyarakat di Puskesmas Rappang.

Undang-Undang Nomor 25 Tahun 2009 tentang pelayanan publik, mendefenisiskan pelayanan publik sebagai upaya pemenuhan kebutuhan pelayanan oleh penyelenggara pelayanan publik yang sesuai dengan aturan perundang-undangan bagis setiap penduduk dan warga negara atas barang, jasa, dan/atau pelayanan administratif yang disediakan. Berdasarkan penjelasan diatas maka pelayanan publik tentu tidak lepas dari kepentingan publik. masyarakat berharap pemerintah selaku menyelenggara pelayanan dapat melayani dengan jujur, mengelola anggaran secara tepat, dan dapat mempertanggung-jawabkannya kepada publik. Menurut Pasolong (2016) kualitas pada dasarnya mempunyai arti relatif karena bersifat abstrak, kualitas dapat digunakan untuk menentukan atau menilai tingkat kesesuaian suatu hal terhadap persyaratan atau spesifikasinya. Bila persyaratan itu terpenuhi maka kualitas hal yang dimaksud dapat dikatakan baik, begitupun sebaliknya jika persyaratan dari hal yang dimaksud tidak terpenuhi maka dapat dikatakan tidak baik.

Taufiqurokhman dkk. (2018) Kualitas pelayanan publik adalah hasil interaksi dari berbagai aspek, diantaranya yaitu sistem pelayanan, strategi, sumber daya manusia (selaku pemberi layanan), dan pelanggan. Sehingga kualitas pelayanan dapat didefinisikan seberapa jauh perbedaan antara harapan dengan kenyataan para penerima layanan atas pelayanan yang diterimanya. Berry, Parasuraman, \& Zeithaml meringkas sepuluh dimensi yang telah disebutkan sebelumnya menjadi SERVQUAL lima 
dimensi (tiga dimensi asli dan dua gabungan). Berikut definisi ringkas untuk kelima dimensi tersebut:

1. Tangibles (bukti fisik): fasilitas fisik, peralatan, dan penampilan pegawai.

2. Reliability (keandalan): kemampuan untuk memberikan pelayanan yang dapat diandalkan dan akurat sesuai yang dijanjikan.

3. Responsiveness (daya tanggap): kemauan untuk membantu pelanggan dan memberikan pelayanan yang cepat.

4. Assurance (jaminan): pengetahuan dalam hal kesopanan karyawan dan kemampuan mereka untuk menginspirasi kepercayaan dan kepercayaan diri.

5. Empathy (kepedulian): kepedulian, perhatian pegawai perusahaan yang diberikan kepada pelanggannya.

Indeks Kepuasan Masyarakat (IKM) adalah data dan informasi mengenai tingkat kepuasan masyarakat terkait dengan pelayanan yang diberikan oleh aparatur penyelenggara pelayanan publik yang diperoleh dari hasil pengukuran secara kualitatif dan kuantitatif atas pendapat masyarakat terhadap pelayanan yang diterimanya. Prinsip pelayanan dalam Keputusan Mentri Pendayagunaan Aparatur Negara No. 63/KEP/M.PAN/2003 ada 14 unsur yang valid, relevan serta reliebel, sebagai unsur dasar pengukuran indeks kepuasan masyarakat yang harus ada yaitu sebagai berikut :

1. Prosedur pelayanan, yaitu kesederhanaan alur pelayanan yang memudahkan tahapan pelayanan yang diberikan kepada masyarakat selaku penerima layanan.

2. Persyaratan pelayanan, yaitu persyaratan administratif dan teknis yang diperlukan untuk mendapatkan pelayanan sesuai jenis pelayanan yang dibutuhkan.

3. Kejelasan tugas pelayanan, yaitu kepastian keberadaan petugas yang memberikan pelayanan misalnya, kejelasan mengenai nama, jabatan, kewenangan serta tanggung jawab.

4. Kedisiplinan petugas pelayanan, yaitu petugas yang memberikan pelayanan konsisten dalam hal waktu kerja sesuai dengan ketentuan yang berlaku.

5. Tanggungjawab petugas pelayanan, yaitu tanggung jawab petugas atas wewenang yang dimilikinya dalam penyelenggaraan pelayanan.

6. Kemampuan petugas pelayanan, yaitu tingkat keahlian atau keterampilan yang dimiliki petugas dalam memberikan atau menyelesaikan pelayanan kepada masyarakat.

7. Kecepatan pelayanan, yaitu pelayanan dapat diselesaikan sesuai dengan target atau waktu yang telah ditentukan.

8. Keadilan mendapatkan pelayanan, yaitu dalam memberikan pelayanan tidak ada deskriminasi atau membeda-bedakan golongan maupun status masyarakat yang membutuhkan pelayanan.

9. Kesopanan dan keramahan petugas, yaitu dalam memberikan pelayanan petugas bersikap atau berperilaku dengan sopan, ramah dan saling menghargai kepada masyarakat.

10. Kewajaran biaya pelayanan, yaitu masyarakat mampu menjangkau pembiayaan yang ditetapkan oleh unit pelayanan.

11. Kepastian biaya pelayanan, yaitu biaya yang ditetapkan dengan sesuai dengan biaya yang harus dibayarkan.

12. Kepastian jadwal/pelayanan, yaitu waktu pelaksanaan pelayanan sesuai dengan waktu yang ditetapkan.

13. Kenyamanan lingkungan, yaitu kondisi sarana dan prasarana pelayanan yang bersih, rapi dan teratur sehingga dapat memberikan rasa nyaman kepada penerima pelayanan.

14. Keamanan pelayanan, yaitu terjaminnya keamanan lingkungan ataupun sarana yang digunakan sehingga masyarakat merasa tenang untuk mendapatkan pelayanan dan tidak khawatir terhadap resiko-resiko yang dapat terjadi selama pelaksanaan pelayanan.

\section{B. METODE PENELITIAN}

Metode yang digunakan oleh peneliti adalah deskriptif kuantitatif yaitu penelitian yang mengambarkan permasalahan secara sistematis, faktual dan aktual yang terjadi di lokasi penelitian yaitu menjelaskan tentang Kualitas Pelayanan Publik terhadap Indeks Kepuasan Masyarakat di Puskesmas Rappang. Untuk membuktikan hipotesis yang telah di tentukan diterima atau tidak dilakukan tahap analisis dengan menggunakan statistk deskriptif. 
Data yang digunakan dalam hal ini, baik data primer maupun data sekunder, dipergunakan beberapa bentuk pengumpulan data yaitu Angket atau kusioner, Observasi, dan Studi Pustaka sedangkan teknik analisis data yang digunakan yaitu Model analisis yang digunakan dalam penelitian ini adalah analisis regresi sederhana Kualitas Pelayanan terhadap Indeks Kepuasan Masyarakat di Puskesmas Rappang, Analisis regresi sederhana digunakan untuk memprediksi nilai koefisien regresi dari masing-masing variabel penelittian, yakni indeks kepuasan masyarakat (variabel $Y$ ) jika kualitas pelayanan (variabel $X$ ) akan dinaikkan atau diturunkan. Selain itu, analisis regresi sederhana juga digunakan untuk mengetahui nilai $t$ hitung sebagai dasar pengujian hipotesis penelitian.

\section{HASIL DAN PEMBAHASAN}

Berdasarkan hasil penelitian dari keselurah indikator kualitas pelayanan digunakan untuk mengukur Kualitas pelayanan yang ada di Puskesmas Rappang diperoleh hasil Tangibles (wujud fisik) sebesar 48,8\%, Responsiveness (ketanggapan sebesar $60,2 \%$, Reliability (kehandalan)) sebesar 39,5\%, Assurance (jaminan) sebesar $69,7 \%$ dan Empathy (kepedulian) sebesar 66,2\%. Dari kelima indikator di peroleh hasil keseluruhan sebesar 56,8\%. Maka, dapat disimpulkan bahwa kualitas pelayanan yang ada di Puskesmas Rappang berada pada kategori kurang baik.

Berdasarkan hasil penelitian dari keselurah indikator indeks kepuasan masyarakat yang digunakan untuk mengukur kepuasan masyarakat di Puskesmas Rappang diperoleh hasil:

Prosedur pelayanan sebesar $59,2 \%$

Persyaratan pelayanan sebesar $66,5 \%$ c) Kejelasan tugas pelayanan sebesar $71,5 \%$ d) Kedisiplinan petugas pelayanan sebesar $40,5 \%$ e) Tanggungjawab petugas pelayanan sebesar $49,2 \% \quad$ f) Kemampuan petugas pelayanan sebesar $70 \%$ g) Kecepatan pelayanan sebesar $47,2 \%$ h) Keadilan mendapatkan pelayanan sebesar $49 \%$ i) Kesopanan dan keramahan petugas sebesar $68 \%$ j) Kewajaran biaya pelayanan sebesar $75,2 \%$ k) Kepastian biaya pelayanan sebesar $73,2 \% \quad$ I) Kepastian jadwal /pelayanan sebesar $62,5 \%$

Kenyamanan lingkungan sebesar $35,5 \%, \mathrm{n}$ ) Keamanan pelayanan sebesar $71,7 \%$ Dari keempat belas indikator di peroleh hasil $60 \%$. Maka, dapat disimpulkan bahwa indeks kepuasan masyarakat yang ada di Puskesmas Rappang berada pada kategori kurang baik.

Berdasarkan hasil perhitungan t-test pada pengujian hipotesis penelitian Hasil perhitungan tersebut menunjukkan bahwa kualitas pelayanan publik berpengaruh secara postitif dan signifikan terhadap indeks kepuasan masyarakat. Pengaruh Kualitas Pelayanan terhadap Indeks Kepuasan Masyarakat sebesar $55,7 \%$ dan sisanya yaitu $44,3 \%$ yang di pengaruhi oleh variabel lain yang tidak masuk dalam kerangka konsep penelitian ini.

1. Indikator Kualitas Pelayanan Publik

Indikator kualitas pelayanan publik yang pertama yaitu tangibles. Tangibles (bukti fisik) adalah fasilitas fisik, peralatan, dan penampilan pegawai. Bukti fisik yang dimaksud di sini adalah fasilitas yang ada di ruang tunggu berupa kipas angin dan kursi serta ketersediaan pegawai yang ada di Puskesmas Rappang yang masih kurang memadai dengan hasil rata-rata persentase yang diperoleh sebesar $47,2 \%$.

Indikator kualitas pelayanan publik yang kedua yaitu reliability. Reliability (keandalan) yaitu kemampuan untuk memberikan pelayanan yang dapat diandalkan dan akurat sesuai yang dijanjikan. Keandalan yang dimaksud di sini adalah komitmen pegawai dalam menjamin waktu pelayanan sesuai standar prosedur pelayanan di Puskesmas Rappang yang masih kurang tepat waktu dengan rata-rata persentase yang diperoleh sebesar $39,5 \%$.

Indikator kualitas pelayanan publik yang ketiga yaitu responsiveness. Responsiveness (daya tanggap) yaitu kemauan untuk membantu pelanggan dan memberikan pelayanan yang cepat. Daya tanggap yang dimaksud disini adalah kemampuan pegawai dalam merespon apa yang dibutuhkan oleh masyarakat yang datang berobat di Puskesmas Rappang yang sudah baik dengan rata-rata persentase yang diperoleh sebesar $60,2 \%$.

Indikator kualitas pelayanan publik yang keempat yaitu assurance. Assurance (jaminan) yaitu pengetahuan dan kesopanan 
karyawan dan kemampuan mereka untuk menginspirasi kepercayaan dan kepercayaan diri. Jaminan yang dimaksud di sini adalah kesopanan pegawai Puskesmas Rappang dalam memberikan pelayanan yang dianggap sopan dengan rata-rata persentase yang diperoleh sebesar $69,7 \%$.

Indikator kualitas pelayanan publik yang kelima yaitu empathy. Empathy (kepedulian) yaitu kepedulian, perhatian pegawai perusahaan yang diberikan kepada pelanggannya. Yang dimaksud di sini adalah kepedulian pegawai yang bertugas dalam memahami apa yang dikeluhkan atau dibutuhkan oleh masyarakat yang datang berobat di Puskesmas Rappang yang dianggap peduli dengan rata-rata persentase yang diperoleh sebesar $66,2 \%$.

2. Indikator Indeks Kepuassan Masyarakat

Indikator indeks kepuasan masyarakat yang pertama adalah prosedur pelayanan. Prosedur pelayanan, yaitu kesederhanaan alur pelayanan yang memudahkan tahapan pelayanan yang diberikan kepada masyarakat selaku penerima layanan. Yang dimaksud disini adalah kesederhanan prosedur pelayanan yang memudahkan pasien dalam menerima pelayanan di Puskesmas Rappang yang dianggap kurang mudah dengan dengan rata-rata persentase yang diperoleh sebesar $59,2 \%$.

Indikator indeks kepuasan masyarakat yang kedua adalah persyaratan pelayanan. Persyaratan pelayanan, yaitu persyaratan teknis dan administratif yang diperlukan untuk mendapatkan pelayanan sesuai dengan jenis pelayanan yang dibutuhkan. Yang dimaksud disini adalah informasi mengenai syarat yang harus dipenuhi oleh pasien untuk bisa menerima pelayanan di Puskesmas Rappang yang dianggap mudah dengan dengan ratarata persentase yang diperoleh sebesar $66,5 \%$.

Indikator indeks kepuasan masyarakat yang ketiga adalah kejelasan tugas pelayanan. Kejelasan tugas pelayanan, yaitu kepastian keberadaan petugas yang memberikan pelayanan misalnya, kejelasan mengenai nama, jabatan, serta kewenangan dan tanggung jawab. Yang dimaksud di sini adalah kejelasan tugas pegawai yang bertugas memberikan pelayanan di Puskesmas Rappang yang dianggap jelas dengan dengan rata-rata persentase yang diperoleh sebesar $71,5 \%$.
Indikator indeks kepuasan masyarakat yang keempat adalah kedisiplinan petugas pelayanan. Kedisiplinan petugas pelayanan, yaitu petugas yang memberikan pelayanan konsisten dalam hal waktu kerja sesuai dengan ketentuan yang berlaku. Yang dimaksud di sini adalah kedisiplinan pegawai yang bertugas memberikan pelayanan di Puskesmas Rappang yang dianggap kurang disiplin dengan dengan rata-rata persentase yang diperoleh sebesar $40,5 \%$.

Indikator indeks kepuasan masyarakat yang kelima adalah tanggungjawab petugas pelayanan. Tanggungjawab petugas pelayanan, yaitu tanggungjawab petugas atas wewenang yang dimilikinya dalam penyelenggaraan pelayanan. Yang dimaksud di sini adalah rasa tanggungjawab yang dimiliki pegawai dalam memberikan pelayanan di Puskesmas Rappang yang dianggap kurang bertanggungjawab dengan dengan rata-rata persentase yang diperoleh sebesar $49,2 \%$.

Indikator indeks kepuasan masyarakat yang keenam adalah kemampuan petugas pelayanan. Kemampuan petugas pelayanan, yaitu keahlian atau keterampilan yang dimiliki petugas dalam memberikan dan menyelesaikan pelayanan kepada masyarakat. yang di maksud di sini adalah kemampuan atau keterampilan pegawai yang bertugas dalam memberikan pelayanan di Puskesmas Rappang yang dianggap baik dengan rata-rata persentase yang diperoleh sebesar $70 \%$.

Indikator indeks kepuasan masyarakat yang ketujuh adalah kecepatan pelayanan. Kecepatan pelayanan, yaitu pelayanan dapat diselesaikan sesuai dengan target atau waktu yang telah ditentukan. Yang dimaksud di sini kecepatan pegawai yang bertugas dalam menyelesaikan pelayanan di Puskesmas Rappang yang dianggap kurang baik dengan rata-rata persentase yang diperoleh sebesar $47 \%$.

Indikator indeks kepuasan masyarakat yang kedelapan adalah keadilan mendapatkan pelayanan. Keadilan mendapatkan pelayanan, yaitu dalam memberikan pelayanan tidak adda deskriminasi atau membeda-bedakan golongan maupun status masyarakat yang membutuhkan pelayanan. Yang dimaksud disini adalah pegawai yang bertugas bersikap adil dalam memberikan pelayanan di 
Puskesmas Rappang yang dianggap kurang adil dengan dengan rata-rata persentase yang diperoleh sebesar $49 \%$.

Indikator indeks kepuasan masyarakat yang kesembilan adalah kesopanan dan keramahan petugas. Kesopanan dan keramahan petugas, yaitu dalam memberikan pelayanan petugas bersikap atau berperilaku dengan sopan, ramah dan saling menghargai kepada masyarakat. Yang dimaksud di sini adalah keramahan pegawai Puskesmas Rappang dalam memberikan pelayanan yang dianggap ramah dengan rata-rata persentase yang diperoleh sebesar $68 \%$.

Indikator indeks kepuasan masyarakat yang kesepuluh adalah kewajaran biaya pelayanan. Kewajaran biaya pelayanan, yaitu masyarakat mampu menjangkau pembiayaan yang ditetapkan oleh unit pelayanan. Yang dimaksud di sini adalah kewajaran biaya yang harus dibayar oleh pasien dalam menerima pelayanan di Puskesmas Rappang yang dianggap baik dengan rata-rata persentase yang diperoleh sebesar $75,2 \%$.

Indikator indeks kepuasan masyarakat yang kesebelas adalah kepastian biaya pelayanan. Kepastian biaya pelayanan, yaitu biaya yang ditetapkan sesuai dengan biaya yang harus dibayarkan. Yang dimaksud di sini adalah kepastian biaya pelayanan yang ada di Puskesmas Rappang yang dianggap baik dengan rata-rata persentase yang diperoleh sebesar $73,2 \%$.

Indikator indeks kepuasan masyarakat yang kedua belas adalah kepastian jadwal/pelayanan. Kepastian jadwal/pelayanan, yaitu waktu pelaksanaan pelayanan sesuai dengan waktu yang telah ditetapkan. Yang dimaksud di sini adalah kemampuan pegawai dalam mengatur dan menetapkan jadwal pemberian pelayanan kepada pasien di Puskesmas Rappang yang dianggap baik dengan rata-rata persentase yang diperoleh sebesar $62,5 \%$.

Indikator indeks kepuasan masyarakat yang ketiga belas adalah kenyamanan lingkungan. Kenyamanan lingkungan, yaitu kondisi sarana dan prasarana pelayanan bersih, rapi dan teratur sehingga dapat memberikan rasa nyaman kepada penerima pelayanan. Yang dimaksud di sini adalah kenyamanan lingkungan di Puskesmas Rappang yang dianggap tidak nyaman dengan rata-rata persentase yang diperoleh sebesar $35,5 \%$.
Indikator indeks kepuasan masyarakat yang kempat belas adalah keamanan pelayanan. Keamanan pelayanan, yaitu terjaminnya keamanan lingkungan ataupun sarana yang digunakan sehingga masyarakat merasa tenang untuk mendapatkan dan tidak khawatir terhadap resiko- resiko yang terjadi selama pelaksanaan pelayanan. Yang dimaksud adalah keamananan pasien dalam menerima pelayanan di Puskesmas Rappang yang dianggap aman dengan rata-rata persentase yang diperoleh sebesar $77,7 \%$.

3. Pengaruh Kualitas Pelayanan Publik terhadap Indeks Kepuasan Masyarakat

Kepuasan pelanggan (masyarakat) dapat dicapai apabila aparatur pemerintah yang terlibat, baik langsung maupun tidak langsung dalam pelayanan, dapat mengerti dan menghayati, serta berkeinginan untuk melaksanakan pelayanan prima. Kepuasan masyarakat bergantung pada kualitas pelayanan yang diterimanya. Berdasarkah hasil olahan data kuisioner menggunakan SPSS 21 diperoleh hasil nilai $\mathrm{R}$ Square sebesar $55,7 \%$ yang berarti bahwa kualitas pelayanan publik mempunyai pengaruh yang signifikan terhadap indeks kepuasan masyarakat di Puskesmas Raappang sebesar $55,7 \%$. Jika kualitas pelayanan meningkat maka indeks kepuasan masyarakat juga akan meningkat.

Berdasarkan model summary diperoleh nilai $R=0,746$ sedangkan nilai koefisiensi determinasi $R$ Square $\left(R^{2}\right)$ sebesar 0,557 . Koefisiensi determinasi $R$ Square $\left(R^{2}\right)$ digunakan untuk mengetahui besar pengaruh variabel $\mathrm{X}$ terhadap Variabel $\mathrm{Y}$. $\mathrm{R}$ Square : $0,557 \times 100=55,7 \%$ (pengaruh dari variabel $X$ terhadap variabel $Y$ ). Sisanya $100 \%$ $55,7 \%=44,3 \%$ (sisanya di pengaruhi oleh variabel lain). Jadi Pengaruh Kualitas Pelayanan terhadap Indeks Kepuasan Masyarakat sebesar $55,7 \%$ dan sisanya yaitu $44,3 \%$ yang di pengaruhi oleh variabel lain yang tidak masuk dalam kerangka konsep penelitian ini.

Hasil olah data ANOVA pada tabel 4.29 diketahui nilai $F_{\text {hitung }}$ sebesar 120,514 dengan tingkat signifikan sebesar $0,000(F>0,01)$. Karena nilai $F$ lebih besar dari 0,01 maka diperoleh hasil bahwa variabel kualitas pelayanan publik mempunyai pengaruh yang signifikan terhadap variabel indeks kepuasan masyarakat. Nilai signifikan sebesar 0,000 lebih kecil dari 0,05 berarti model regresi 
dapat digunakan untuk memprediksi Kualitas pelayanan Publik. Coefficients hasil olah data, model regresi yang digunakan dalam penelitian ini untuk mengukur kualitas pelayanan publik terhadap indeks kepuasan masyarakat di Puskesmas Rappang, akan dianalisa sebagai berikut.

Fungsi regresi di atas, maka dapat dijelaskan :

1. Jika variabel kualitas pelayanan publik $(X)$ berubah, maka indeks kepuasan masyarakat $(Y)$ juga akan berubah. Tanda positif menunjukkan perubahan searah. Apabila kualitas pelayanan publik meningkat, maka indeks kepuasan masyarakat juga ikut meningkat dengan koefisien regresi sebesar 1,51 dan sebaliknya, jika kualitas pelayanan publik menurun, maka indeks kepuasan masyarakat juga ikut menurun dengan koefisien regresi sebesar 1,51.

2. Nilai konstanta sebesar 10,38 menunjukkan bahwa, jika variabel kualitas pelayanan publik konstan, maka indeks kepuasan masyarakat masih bersifat positif.

Uji statistik $t$ untuk menunjukkan seberapa besar pengaruh satu variabel penjelas/independen secara individual menerangkan variasi variabel dependen berdasarkan tabel 4.30 Coefficients di atas maka diketahui bahwa :

1. Nilai $t$ hitung $=$ variabel kualitas pelayanan publik sebesar 10,978 dengan tingkat signifikan 0,000

2. $\mathrm{HO}=$ Tidak terdapat pengaruh Kualitas Pelayanan Publik terhadap Indeks Kepuasan Masyarakat di Puskesmas Rappang Kecamatan Panca Rijang Kabupaten Sidenreng Rappang.

$\mathrm{Ha}=$ Terdapat pengaruh/signifikan antara Kualitas Pelayanan Publik terhadap Indeks Kepuasan Masyarakat di Puskesmas Rappang Kecamatan Panca Rijang Kabupaten Sidenreng Rappang.

3. Kaidah Keputusan :
a. Jika nilai $t$ hitung $\geq t$ tabel, maka $H 0$ ditolak dan $\mathrm{Ha}$ diterima, artinya signifikan.
b. Jika nilai $\mathrm{t}$ hitung $\leq \mathrm{t}$ tabel, maka $\mathrm{HO}$ diterima dan $\mathrm{Ha}$ ditolak, artinya tidak signifikan.

4. tabel 4.30 Coefficients diperoleh $t$ hitung $=$ 10,978 prosedur mencari statistic tabel dengan kriteria a. Tingkat signifikan $(a=0,05)$

b. $\mathrm{df}=$ jumlah responden -2 atau $98-2$ $=96$

c. $t$ table $=a / 2 ; d f$

$$
=0,05 / 2 ; \mathrm{df}
$$$$
=0,025 ; 96
$$

Sehingga $\mathrm{t}$ tabel $=1,984$

Karena nilai $t_{\text {hitung }}>\mathrm{t}_{\text {tabel }}(10,978>$

1,984) maka HO ditolak dan Ha diterima, artinya signifikan. Jadi, Kualitas Pelayanan Publik berpengaruh/signifikan terhadap Indeks Kepuasan Masyarakat di Puskesmas Rappang Kecamatan Panca Rijang Kabupaten Sidenreng Rappang.

\section{SIMPULAN}

1. Berdasarkan hasil penelitian dari kualitas pelayanan publik, maka disimpulkan bahwa kualitas pelayanan di Puskesmas Rappang berada pada kategori kurang baik dengan rata-rata persentase sebesar $56,8 \%$.

2. Berdasarkan hasil penelitian dari indeks kepuasan masyarakat, maka disimpulkan bahwa indeks kepuasan masyarakat di Puskesmas Rappang berada pada kategori kurang baik dengan rata-rata persentase $60 \%$.

3. Berdasarkan hasil penelitian dan ppembahasan diperoleh nilai keseluruhan untuk kualitas pelayanan publik terhadap indeks kepuasan masyarakat di Puskesmas Rappang dengan rata-rata persentase sebesar $55,7 \%$ berpengaruh signifikan.

\section{E. DAFTAR PUSTAKA}

Ahmad, J. (2015). Metode Penelitian Administrasi Publik Teori dan Aplikasi. Penerbit Gava Media: Yogyakarta. Yogyakarta: 2015.

Berry, L. L., Parasuraman, A., \& Zeithaml, V. A. (1988). SERVQUAL: A multiple-item scale for measuring consumer perceptions of service quality. Journal of Retailing, 64(1), 12-40.

Kamaruddin Sellang, M. D. (2016). Administrasi dan Pelayanan Publik Antara Teori dan Aplikasi. Yogyakarta: Penerbit Ombak.

Marlindawaty. (2014). Analisis Kualitas Pelayanan Kesehatan Publik Di Rumah 
Sakit Khusus Bersalin (Rskb) Sayang Ibu Balikpapan, 15(1), 147-177.

Pasolong, H. (2016). Teori Administrasi Publik. Bandung: Penerbit Alfabeta.

Sahya Anggara. (2012). IImu Administrasi Negara (Kajian Konsep, Teori, dan Fakta dalam Upaya Menciptakan Good Governance). Bandung: CV PUSTAKA SETIA. Retrieved from http://digilib.uinsgd.ac.id/

Samad, Z. (2016). Birokrasi dalam Pelayanan Publik. Yogyakarta: Penerbit Ombak.

Sedarmayanti. (2013). Reformasi Administrasi Publik , Reformasi Birokrasi, dan Kepemimpinan Masa Depan. (S. A. Mifka, Ed.). Bandung: PT Refika Aditama.

Sinambela, L. P., Rochadi, S., Ghazali, R., Muksin, A., Setiabudi, D., Bima, D., \& Syaifudin. (2014). Reformasi Pelayanan Publik Teori, Kebijakan, dan Implementasi. Jakarta: PT Bumi Aksara.

Sudana, R. (2016). Kualitas Pelayanan Dalam Meningkatkan Kepuasan Pengunjung Di Upt Perpustakaan Universitas Riau. Journal of Chemical Information and Modeling, 53(9), 16891699.

Sugiyono. (2016). Metode Penelitian Kuantitatif, Kualitatif dan R\&D. Bandung: Alfabeta

Taufiqurokhman, Satispi, \& Evi. (2018). Perkembangan Manajemen Pelayanan Publik Teori Dan Perkembangan Manajemen Pelayanan Publik. Tangerang Selatan: UMJ PRESS.

Zainuddin. (2017). Teori-Teori Mutakhir Dalam Perfektif IImu Administrasi Publik.pdf. Makassar: Phinatama Media.

\section{Dokumen :}

Undang-Undang Republik Indonesia Nomor 25 Tahun 2009 Tentang Pelayanan Publik.
Keputusan Menteri Pendayagunaan Aparatur Negara Nomor : KEP/25/M.PAN/2/2004 tentang Pedoman Umum Penyusunan Indeks Kepuasan Masyarakat Unit Pelayanan Instansi Pemerintah. 